\title{
MOneyQU: A Gamified Android Based Personal Finance Recording Application
}

\author{
Firdayanti Juwono', Dennis Gunawan² \\ Department of Informatics \\ Universitas Multimedia Nusantara \\ Tangerang, Indonesia \\ e-mail: cfirdayantij@gmail.com , dennis.gunawan@umn.ac.id
}

To cite this document:

Juwono, F., \& Gunawan, D. (2020). MOneyQU: A Gamified Android Based Personal Finance Recording Application. IAIC Transactions on Sustainable Digital Innovation (ITSDI), 2(2), 107-120.

DOI: https://doi.org/10.34306/itsdi.v2i2.388

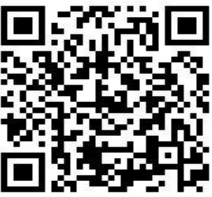

Author Notification 22 November 2020 Final Revised

25 November 2020 Published

26 November 2020

\begin{abstract}
Financial management is a knowledge which is not only important to learn but also important to be applied in the life of each individual. In recognizing financial conditions, motivation can be one of the factors which influence it. Gamification can be one way to increase the motivation and must be adapted to the characteristics of the users. Focusing on goals, engagement, and intrinsic motivation, Marczewski Gamification Framework maps several user types based on the game elements and mechanics. This study aims to design and build a mobile-based personal financial recording application with gamification methods and find out the level of behavioral intention to use and immersion implementing the Marczewski Gamification Framework. Testing has been carried out by students, employees, housewives, entrepreneurs, and managers to prove that gamification can motivate users to recognize the condition of personal finances well. Based on the evaluation result using the Hedonic Motivation System Adoption Model, $82.73 \%$ strongly agree that the application can increase reuse (behavioral intention to use) in the future and $66.56 \%$ agree that the application can increase the feeling of users to be carried away by the situation (immersion) in the application.
\end{abstract}

Keywords: Android-based application; Hedonic Motivation System Adoption Model; Marczewski gamification framework; MOneyQU; personal finance recording 


\section{Introduction}

Gross Domestic Product (GDP) is a broad measurement of a nation's overall economic activity. GDP provides a direct indication of the health and growth of the economy. Businesses can use GDP as a guide to their business strategy. Investors also watch GDP since it provides a framework for investment decision-making [1]. Although Indonesia's economies which was ranked 16th respectively in 2014, will move up to fourth and eighth, knocking Italy and Russia out of the top ten [2]. President Joko Widodo (Jokowi) still feels dissatisfied with the condition of Indonesia's economy which is still relatively weak, where economic growth in various sectors lacks the impact on improving the quality of life of the Indonesian people as a whole [3]. This can be seen from the quote from CnnIndonesia.com which says that the Otoritas Jasa Keuangan (OJK) noted that only 12.6 percent of Indonesians were aware of financial planning so that according to the OJK one way to increase this awareness was by increasing financial literacy [4]. Financial literacy for individuals is not just a science but it can make individuals wiser in managing their assets [5].

Motivation can be one of the factors that influence financial literacy as written in the literature study on motivation as a determinant of financial planning. It said that people who are highly motivated will trigger behaviors to increase financial literacy in making a regular and careful financial plan to realize financial freedom [6].

Gamification is the use of design elements that shape a game into a non-game context to increase user involvement and trigger something to do [7]. Most studies review usage of gamification in many areas, such as health [8,9,10], tourism [11], software engineering [12], online discussions [13], education [14,15,16], marketing [17], and employee training [18].

In order to ensure users to be fully engaged in gamification, designers have to understand what motivates users and how game elements address these needs [19]. Personality differences make people attracted to information systems and games for different reason and needs [19]. As characteristics of different users do not increase the expected motivation, gamification must be adapted to the characteristics of the users [20]. To know the motivations of the users of the application, the typologies of player profiles can be used [8]. These typologies group common characteristics of players based on psychological factors, preferences, or motivations, to perform the classification [8]. Marczewski described six types of users at a basic level [21]. These user types preferences are mapped and validated based on the 52 game elements and mechanics classified in Marczewski's Gamification Elements Periodic Table [21].

This research will design and build an application for recording personal finance by highlighting the user type achiever because Gabe Zicherman said that one of the main problems in personal finance is about the desire to get a reward [22]. Intrinsic and extrinsic rewards are the most effective gamification elements to show good abilities of the user and make the user want to do more [22]. Some game elements, such as badges, can be used as rewards and can increase user participation and involvement [23]. It is necessary to think about the user not only as a "player" who will receive a reward for an effort, but the user should also be responsible for building knowledge, and gamification is an opportunity to make this process funnier and more challenging according to his skills [24].

Nevertheless, at times extrinsic motivation may be all you have to get a system kick-started, but you cannot rely on it for long [25]. Applying an own motivation framework called RAMP (Relatedness, Autonomy, Mastery, Purpose), Marczewski Gamification Framework focuses on goals and engagement [9] and focuses more on intrinsic motivation [25]. Therefore, users keep track of personal finances because of self-awareness as an intrinsic motivation. 


\section{Research Method}

\section{A. Application Model}

The personal financial record application which implements a gamification method generally functions to record and view personal expenses and income on an Android basis both in the form of lists and statistics. Fig. 1 shows the MOneyQU application model. By using this application, the user can make financial records on that date or the date that has passed. This action triggers to add experience points (EXP) and coins owned by the user with a certain amount of EXP and coins. The higher the level the user has, the greater the experience the user must collect to reach the next level. Users can also edit and delete the expenses and income that the user has made. The maximum addition of EXP and coin per day triggered by user entry is a form of fraud prevention that might be done.

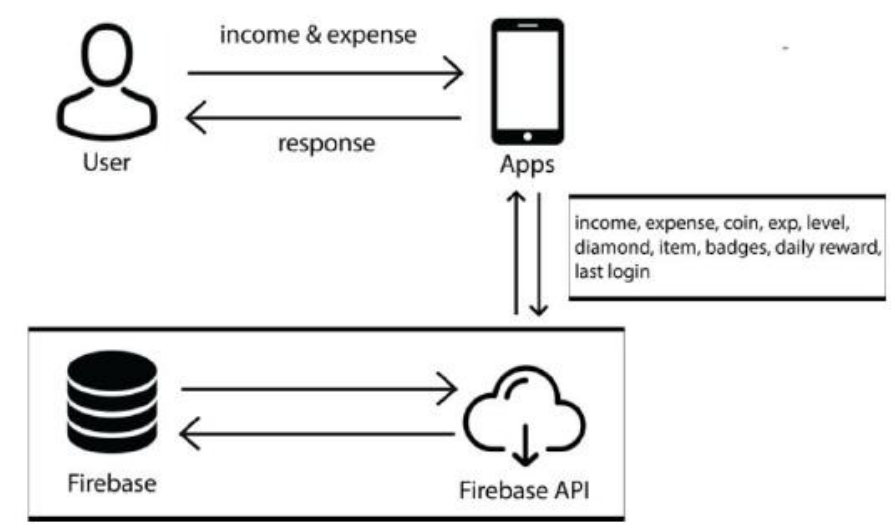

Fig. 1. MOneyQU Application Model

The coin can be used to buy stores and furniture in the shop. Users can employ Non-Playable Characters (NPC) who walk in front of stores in a room that has complete furniture. This is useful for adding coins and EXP from users at any given time period. Speeding up an employee can be done by reducing the user's diamonds. This application will also provide missions so that it encourages users to open applications regularly. It aims to minimize the nature of users who tend to forget to make financial records every day. The mission certainly gives benefits to the user by adding the user's coins and diamonds.

\section{B.Gamification Design}

The design of the gamification is based on Marczewski Gamification Framework, as follows.

WHAT is being gamified: The activity that is gamified is the recording of personal finances both expenses and income.

WHY is it being gamified: The activity was gamified because the Indonesian people needed to increase financial literacy as an action from the low percentage of Indonesians who were just aware of financial planning. Increasing financial literacy can be done by increasing motivation. One method that can help increasing motivation in the financial learning process is the gamification method. 
WHO are the users: Users of this application are students, employees, housewives, entrepreneurs, and managers. The user type of this application more emphasizes an achiever who is more likely to complete each challenge by giving badges as the fulfillment of the wishes of achievers. On the other hand, the user type of a free spirit is motivated by autonomy, the freedom to employ Non-Playable Character (NPC), and the user type of a socializer is motivated by passion in competing between the other users by paying attention to the leaderboard.

HOW is it being gamified: The financial recording application is gamified by implementing game mechanics and game dynamics as shown in Table I.

TABLE I. List of Game Dynamics dan Game Mechanics

\begin{tabular}{|l|l|l|}
\hline \multicolumn{1}{|c|}{ Application Page } & Game Dynamic & \multicolumn{1}{|c|}{ Game Mechanic } \\
\hline Onboarding Page & - & Onboarding \\
\hline $\begin{array}{l}\text { Daily Reward, Badges, } \\
\text { and Add Record Page }\end{array}$ & $\begin{array}{l}\text { Reward } \\
\text { Achievement }\end{array}$ & $\begin{array}{l}\text { Points } \\
\text { Challenges } \\
\text { Badges }\end{array}$ \\
\hline Employee Page & Self-Expression & Points \\
\hline In-Game Page & Self-Expression & $\begin{array}{l}\text { Points } \\
\text { Badges }\end{array}$ \\
\hline Ranking Page & Competition & Leaderboards \\
\hline
\end{tabular}

ANALYTICS are set up: Success rates are measured based on behavioral intention to use and immersion of the application using Hedonic Motivation System Adoption Model (HMSAM). TESTED with users: Several ways in the testing phase to get feedback from the respondents are as follows.

The application is shared through social media, such as Instagram, Line, Linkedln, Facebook, and field study.

Users can download the application on the Play Store.

Users have to sign up to get an account. After having the account, the users can immediately sign in.

The features that can be tried by users are as follows.

Record personal financial expenses and income.

View personal financial history on a daily basis.

View personal finance statistics on a monthly basis.

View the ranking in the leaderboard menu.

View the list of badges that the users already have.

Buy items in the game world by exchanging coins owned.

Employing Non-Player Character (NPC) in a store owned.

Move and fire the employee.

Collecting coins and experience points from the work of the employee.

View a list of employees who have worked at the store.

Activate or deactivate back sound or sound effects in the settings menu.

After getting level two, users can fill out the questionnaire through the link provided.

ACTED on feedback: Feedbacks from users are useful for repairing and developing the application.

RELEASED the solution: The application will be released to the next version when it can run properly according to positive feedback on the Play Store. 


\section{Implementation}

When a user enters the application for the first time, the user will be shown the Sign In page, as can be seen in Fig. 2(a). If the user does not have an account in this application, the user can register first by filling in the data provided on the Sign Up page, as shown in Fig. 2(b). However, if the user already has an account, the user can immediately sign in. When a user has already signed in to the application, the user does not need to sign in again for entering the application on another occasion.

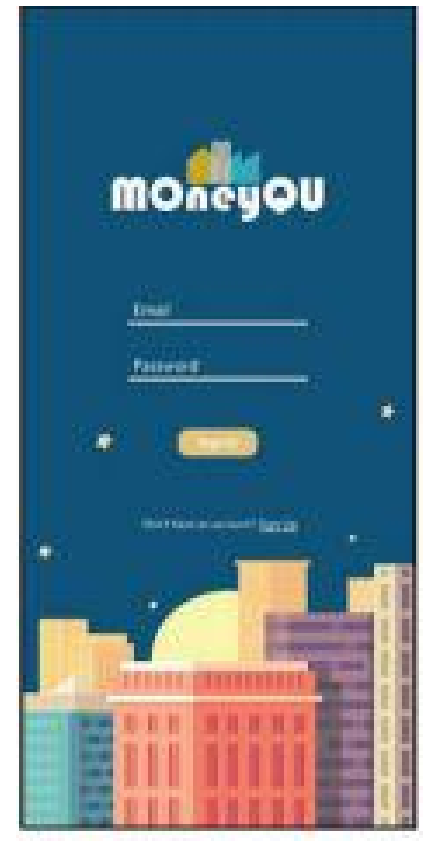

(a)

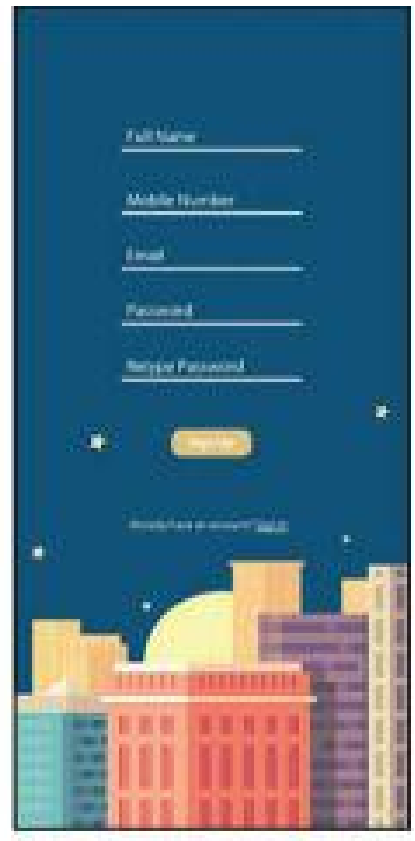

(b)

Fig. 2. (a) Sign In Page (b) Sign Up Page

After signing in for the first time, the user will be shown the tutorial which is onboarding from this application. Then the user will receive a special reward such as a number of coins in order to be able to buy in-game items to give the user experience. In this application, there is a daily reward that the user can get on a daily basis which is useful for giving challenges to users so they are encouraged to make financial records regularly. The daily reward can be seen in Fig. 3(a).

Fig. 3(b) shows a Homescreen Page. On this page, there is a nominal balance located at the bottom of the application. This nominal balance shows the amount of money that the user has for a month. If it is negative, it describes that user expenditure is greater than the income, and vice versa.

The information about the level of the user is located at the top left of the application, whereas coin information, diamond, and add record status are located at the top right. Add record status is an information given to the user regarding the maximum number of points (coins and experience points) that the user can get after making financial records on that day. It is to prevent fraud that may be done by the user.

The user can see the menu in this application by pressing the button that shows the nominal balance. The menu consists of Employee, Statistics, Add Record, History, Shop, Badge, 
Ranking, and Settings.

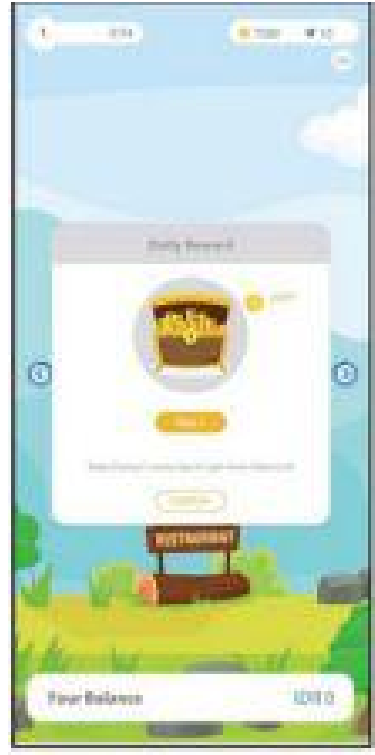

(a)

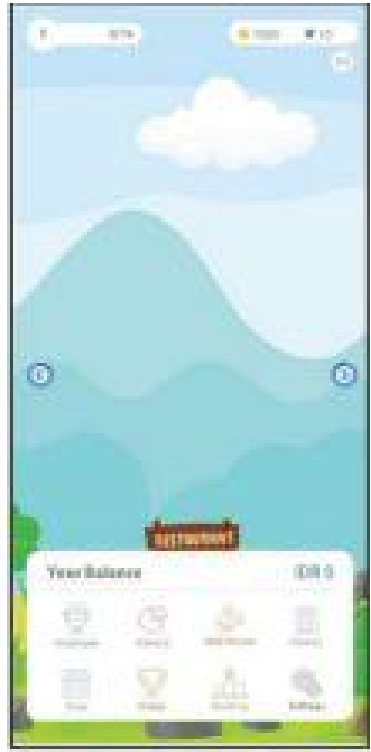

(b)

Fig. 3. (a) Daily Reward (b) Home Screen Page

The Add Record page is useful for financial records. In carrying out financial records, there are two modes: transaction and top up. In transaction mode, the user must input the amount of money and the category of income or expenses, as shown in Fig. 5(a). The categories consist of food, child, entertainment, personal, pet, housing, health, transport, miscellaneous, and income. The money can be in the form of cash, OVO, and GO-PAY. In top up mode, the user only needs to input the amount of money and the top up category (OVO or Go-Pay), as seen in Fig. 5(b). 


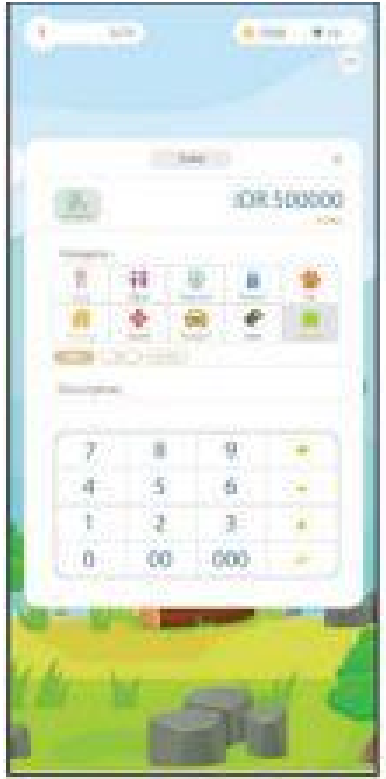

(a)

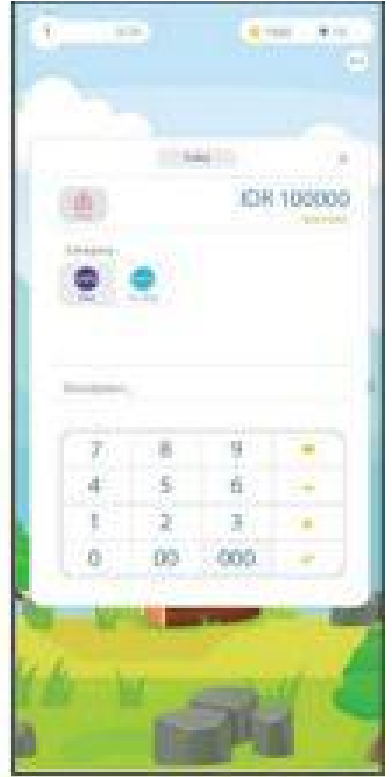

(b)

Fig. 4. Add Record Page (a) Transaction Mode (b) Top Up Mode

The Add Record page is useful for financial records. In carrying out financial records, there are two modes: transaction and top up. In transaction mode, the user must input the amount of money and the category of income or expenses, as shown in Fig. 4(a). The categories consist of food, child, entertainment, personal, pet, housing, health, transport, miscellaneous, and income. The money can be in form of cash, OVO, and GO-PAY. In top up mode, the user only needs to input the amount of money and the top up category (OVO or Go-Pay), as seen in Fig. 4(b).

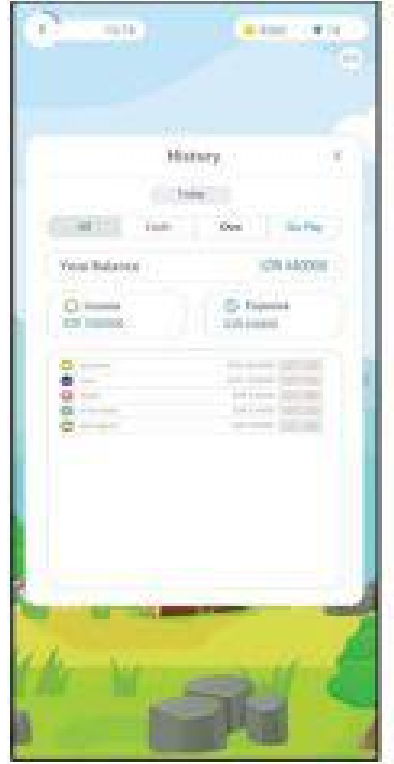

(a)

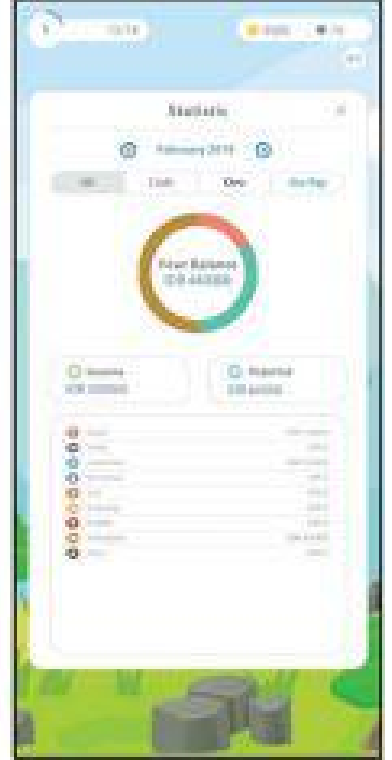

(b) 
Fig. 5. (a) History Page (b) Statistic Page

In making financial records, the user can also choose the date when the user makes the transaction by pressing the button that shows the word "Today". Records created by the user can be seen daily on the History Page and on a monthly basis on the Statistic Page.

Fig. 5(a) shows the History page. On this page, the user can view a list of income or expenses of the user on a daily basis. If the user makes a mistake in writing expenses or financial entries, the user can change or delete them by pressing the edit button or delete button located on each list. The user can also see a list of expenses and income in more detail by selecting a specific type.

Fig. 5(b) shows the Statistic page. This page is useful for viewing monthly income or expenses in general. This page can also be viewed in more detail based on certain type, as on the History Page.

The coins obtained by the user are useful for buying in-game items on the Shop Page, as shown in Fig. 6(a). Purchased items will appear in the game world, as seen in Fig. 6(b). The left button and right button in the middle of the application are useful for viewing other stores in the game world.

Fig. 7(a) shows that the user can employ Non-Player Character (NPC) walking in front of the store. As can be seen in Fig. 7(b), the NPC can only work in a room which already has a complete furniture. NPCs inside the room will produce coins and experience points (EXP) which are useful for increasing levels every certain time period, so it can encourage the user to routinely open the application. Fig. 8(a) shows a display when the user gets to the next level. 


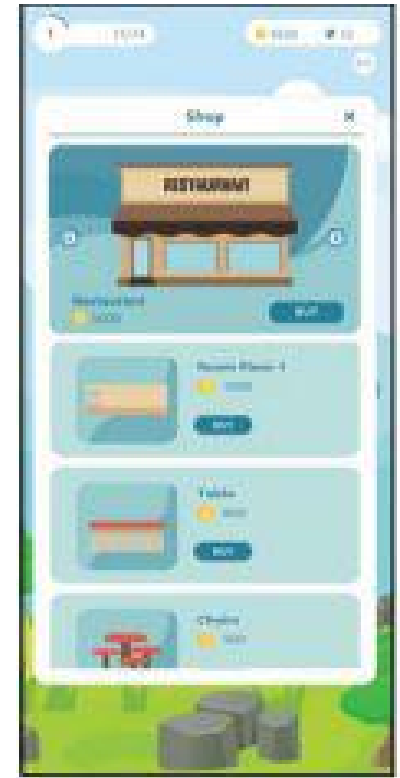

(a)

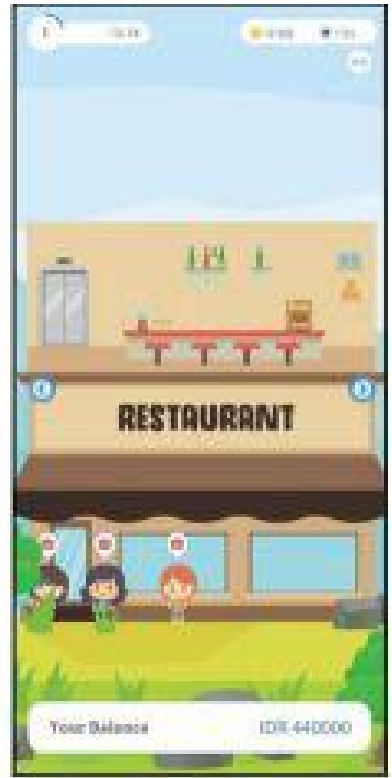

(b)

Fig. 6. (a) Shop Page (b) In-Game Page

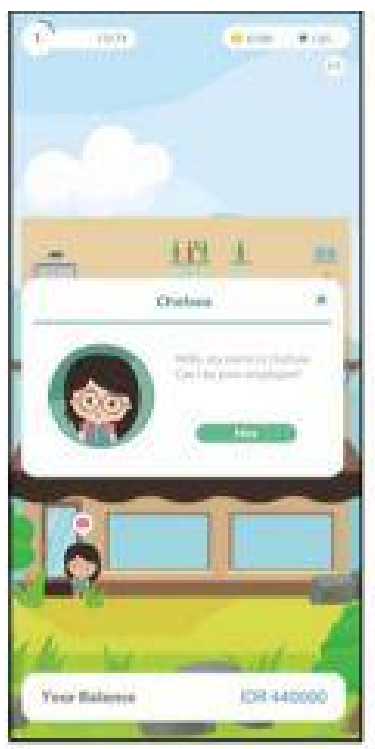

(a)

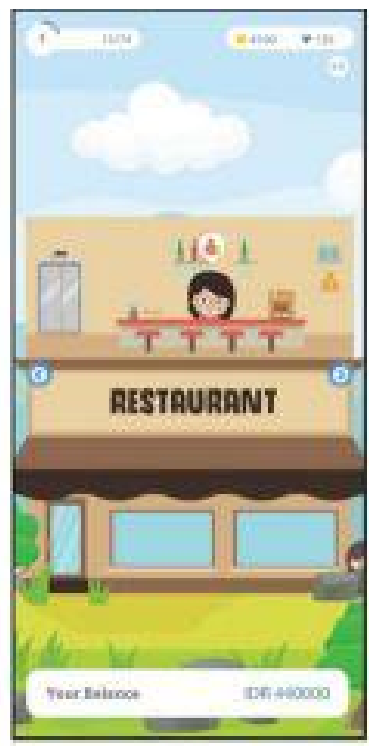

(b)

Fig. 7. (a) Popup Dialog for Hiring NPC (b) Employee Page

In this application, there are twelve badge categories: Food Lover, Cool Parents, Socialite, Shopaholic, Pet Lover, Home Designer, Walking Doctor, Traveler, The Anon, Banker, Accountant, and Digital Home Designer. Fig. 8(b) shows the Badge Page in the Digital Home Designer category, the first part that the user gets after buying three in-game 
items (furniture). If the user has fulfilled the requirements of a particular badge, the user will be able to view the picture of the badge and get coins and diamonds. Otherwise, the user can only see the description of the badge.

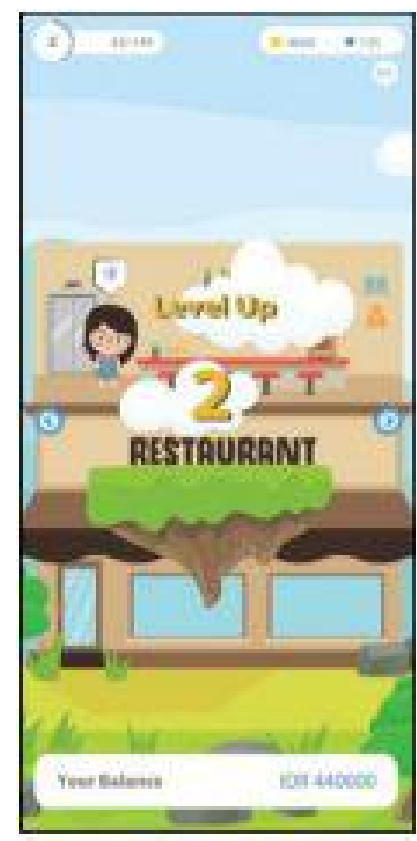

(a)

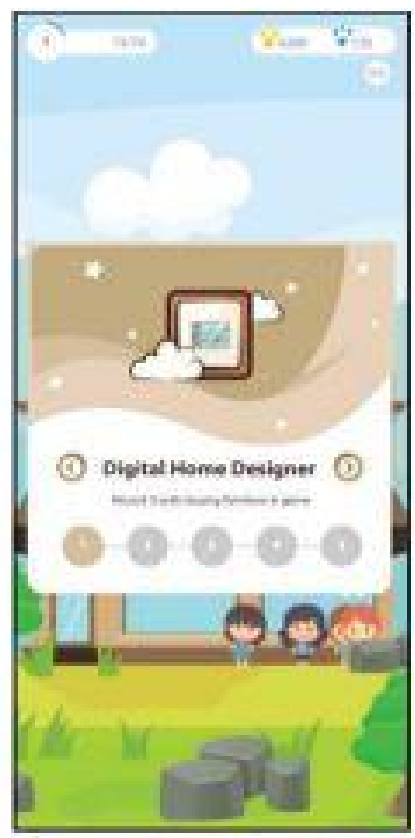

(b)

Fig. 8. (a) Level Up (b) Badge Page

\subsection{Results And Discussion}

The evaluation of MOneyQU is carried out by 39 respondents who voluntarily filled out HMSAM questionnaires to measure two main aspects: behavioral intention to use and immersion. The occupation distribution of the respondents can be seen in Fig. 9 . Respondents of this application consist of students with a percentage of $43.6 \%$, employees with a percentage of $28.2 \%$, housewives with a percentage of $12.8 \%$, entrepreneurs with a percentage of $10.3 \%$, and managers with a percentage of $5.1 \%$. 


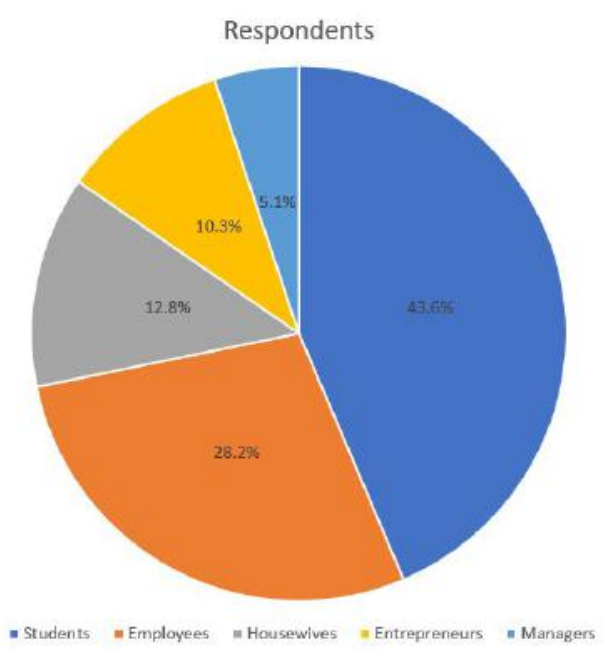

Fig. 9. Demographic Profile of Respondents Based on Occupation

There are several aspects in Hedonic Motivation System Adoption Model: perceived ease of use, perceive usefulness, curiosity, control, joy, behavioral intention to use, and immersion. Table II shows the evaluation results of MOneyQU. Based on the aspects of behavioral intention to use and immersion, $82.73 \%$ strongly agree that the application can increase reuse in the future and $66.56 \%$ agree that the application can increase the feeling of users to be carried away by the situation in the application.

TABLE I. Evaluation Result

\begin{tabular}{|l|l|}
\hline \multicolumn{1}{|c|}{ Aspects } & \multicolumn{1}{c|}{ Result } \\
\hline Perceived ease of use & $85.32 \%$ \\
\hline Perceived usefulness & $79.58 \%$ \\
\hline Curiosity & $83.93 \%$ \\
\hline Control & $77.26 \%$ \\
\hline Joy & $83.07 \%$ \\
\hline Behavioral intention to use & $82.73 \%$ \\
\hline Immersion & $66.56 \%$ \\
\hline Overall & $\mathbf{7 9 . 6 7 \%}$ \\
\hline
\end{tabular}

The aspect with the highest percentage is perceived ease of use with a percentage of $85.32 \%$. The high percentage can be caused by an onboarding element which helps users to know how to use the application. Some users also review that the application is easy to use and has an attractive user interface.

On the other hand, the aspect with the lowest percentage is immersion with a percentage of $66.56 \%$. The low percentage can be caused by the aim of gamification which does not make users become addicted that can block interference, but rather aim to make users become disciplined in doing repetitive activities. 


\section{Conclusion}

A gamified mobile-based personal finance recording application, named MoneyQU, has been successfully designed and developed implementing the Marczewski gamification framework. The application implements intrinsic motivation in forms of mastery and feedback. Several game mechanics, consisting of points, levels, leaderboards, badges, onboarding, and challenges, are also applied.

The application has been evaluated by 39 respondents using Hedonic Motivation System Adoption Model. The evaluation result shows that $82.73 \%$ strongly agree that the application can increase reuse in the future and $66.56 \%$ agree that the application can increase the feeling of users to be carried away by the situation in the application.

As future works, a feature or mechanism which can control user spending can be added. Furthermore, an algorithm can be created and implemented for giving coins to users when income and expenses are input. Therefore, the users are able to manage personal finances properly.

\section{References}

[1] J. CHAPPELOW, "Gross Domestic Product (GDP)," Investopedia, 16 May 2019. [Online]. Available: https://www.investopedia.com/terms/g/gdp.asp.

[2] K. MORIYASU, "Indonesia set to become fourth-largest economy," Nikkei Asian, 25 June 2015.

Available:

https://asia.nikkei.com/Economy/Indonesia-set-to-become-fourth-largest-economy.

[3] M. Subarkah, "Keluh Kesah Jokowi Melihat Kondisi Perekonomian Indonesia," 19 January 2018.

[Online].

Available: http://republika.co.id/berita/ekonomi/keuangan/18/01/19/p2sh4x385-keluh-kesah-jokowi-m elihat-kondisi-perekonomian-indonesia.

[4] S. Primadhyta, "Hanya 12,6 Persen Masyarakat Indonesia Punya Rencana Keuangan," 21 October $2017 . \quad$ [Online]. Available: https://www.cnnindonesia.com/ekonomi/20171020194504-78-249871/hanya-126-persenmasyarakat-indonesia-punya-rencana-keuangan.

[5] A. N. Yushita, "Pentingnya Literasi Keuangan Bagi Pengelolaan Keuangan Pribadi," Nominal, 2017.

[6] P. G. Sina, "Motivasi sebagai Penentu Perencanaan Keuangan (Suatu Studi Pustaka)," IImiah Akuntansi dan Bisnis, p. 43, 2014.

[7] S. Deterding, D. Dixon, R. Khaled dan L. Nacke, "From Game Design Elements to Gamefulness: Defining "Gamification"," Proceedings of the 15th International Academic MindTrek Conference: Envisioning Future Media Environments, pp. 9-15, 2011.

[8] L. Wanderley de Oliveira and S. Teixeira de Carvalho, "A Gamification-Based Framework for mHealth Developers in the Context of Self-Care," 2020 IEEE 33rd International Symposium on Computer-Based Medical Systems (CBMS), Rochester, MN, USA, 2020, pp. 138-141, doi: 10.1109/CBMS49503.2020.00033.

[9] S. A. Mubin and M. Wee Ann Poh, "A Review on Gamification Design Framework: How They Incorporated for Autism Children," 2019 4th International Conference and Workshops on Recent Advances and Innovations in Engineering (ICRAIE), Kedah, Malaysia, 2019, pp. 1-4, doi: 10.1109/ICRAIE47735.2019.9037765. 
[10]S. S. Setiawan and A. Suryadibrata, "Fitrust: Promoting Healthy Lifestyle Through Gamified Mobile Health Application," 2019 5th International Conference on New Media Studies (CONMEDIA), Bali, Indonesia, 2019, pp. 26-30, doi: 10.1109/CONMEDIA46929.2019.8981840.

[11]F. B. P. Prakasa and A. W. R. Emanuel, "Review of Benefit Using Gamification Element for Countryside Tourism," 2019 International Conference of Artificial Intelligence and Information Technology (ICAIIT), Yogyakarta, Indonesia, 2019, pp. 196-200, doi: 10.1109/ICAIIT.2019.8834467.

[12] O. Pedreira, F. García, M. Piattini, A. Cortiñas and A. Cerdeira-Pena, "An architecture for software engineering gamification," in Tsinghua Science and Technology, vol. 25, no. 6, pp. 776-797, Dec. 2020, doi: 10.26599/TST.2020.9010004.

[13]M. Tzelepi, K. Makri, I. Petroulis, M. Moundridou and K. Papanikolaou, "Gamification in online discussions: How do game elements affect critical thinking?," 2020 IEEE 20th International Conference on Advanced Learning Technologies (ICALT), Tartu, Estonia, 2020, pp. 92-94, doi: 10.1109/ICALT49669.2020.00035.

[14]F. Ymran, O. Akeem and S. Yi, "Gamification Design in a History E-Learning Context," 2017 International Conference on Information, Communication and Engineering (ICICE), Xiamen, 2017, pp. 270-273, doi: 10.1109/ICICE.2017.8479194.

[15]A. F. C. Anam Fathoni and D. Delima, "Gamification of learning kanji with "Musou Roman" game," 2016 1st International Conference on Game, Game Art, and Gamification (ICGGAG), Jakarta, 2016, pp. 1-3, doi: 10.1109/ICGGAG.2016.8052664.

[16]Y. Heryadi and K. Muliamin, "Gamification of M-learning Mandarin as second language," 2016 1st International Conference on Game, Game Art, and Gamification (ICGGAG), Jakarta, 2016, pp. 1-4, doi: 10.1109/ICGGAG.2016.8052645.

[17]B. Raj and D. Gupta, "Factors Influencing Consumer Responses to Marketing Gamification," 2018 International Conference on Advances in Computing, Communications and Informatics (ICACCl), Bangalore, 2018, pp. 1538-1542, doi: 10.1109/ICACCI.2018.8554922.

[18]U. Fauziyah, E. R. Kaburuan, G. Wang and Aqsha, "Gamification for Employee Training Platform in Banking Industries," 2019 International Conference on Information Management and Technology (ICIMTech), Jakarta/Bali, Indonesia, 2019, pp. 503-508, doi: 10.1109/ICIMTech.2019.8843750.

[19]D. Codish and G. Ravid, "Adaptive Approach for Gamification Optimization," 2014 IEEE/ACM 7th International Conference on Utility and Cloud Computing, London, 2014, pp. 609-610, doi: 10.1109/UCC.2014.94.

[20] F. Rozi, Y. Rosmansyah and B. Dabarsyah, "A Systematic Literature Review on Adaptive Gamification: Components, Methods, and Frameworks," 2019 International Conference on Electrical Engineering and Informatics (ICEEI), Bandung, Indonesia, 2019, pp. 187-190, doi: 10.1109/ICEEI47359.2019.8988857.

[21] G. F. Tondello, R. R. Wehbe, L. Diamond, M. Busch, A. Marczewski, and L. E. Nacke, "The gamification user types hexad scale," in Proceedings of the 2016 annual symposium on computer-human interaction in play. ACM, 2016, pp. 229-243.

[22]S. J. Taylor, "The 'Gamification' of Personal Finance," 16 July 2012. [Online]. Available: https://money.usnews.com/money/personal-finance/articles/2012/07/16/the-gamification-of -personal-finance.

[23]P. Denny, "The Effect of Virtual Achievements on Student Engagement," Proceedings of the SIGCHI conference on human factors in computing systems, pp. 763-772, 2013.

[24]L. d. R. Seixas, A. S. Gomes and I. J. d. M. Filho, "Effectiveness of gamification in the engagement of students," Computers in Human Behavior, pp. 48-63, 2016. 
[25]A. Marczewski, "Gamification Framework," 2014. [Online]. Available: https://www.gamified.uk/gamification-framework/.

[26] Aziz, M., \& Aman, M. (2019). Decision Support System For Selection Of Expertise Using Analytical Hierarchy Process Method. IAIC Transactions on Sustainable Digital Innovation, 1(1), 49-65.

[27] Soliga, A., \& Jasil, G. (2016). Evaluating Blind Image Quality Using RBF Neural Network. Aptikom Journal on Computer Science and Information Technologies, 1(1), 23-26.

[28] Febriyanto, E., Naufal, R. S., \& budiarty, frizca. (2019). Attitude Competency Assessment in the 2013 curriculum based on elementary school Prototyping methods. IAIC Transactions on Sustainable Digital Innovation (ITSDI), 1(1), 87-96. https://doi.org/10.34306/itsdi.v1i1.6

[29] Yusup, M., Aini, Q., Apriani, D., \& Nursaputri, P. (2019, December). PEMANFAATAN TEKNOLOGI BLOCKCHAIN PADA PROGRAM SERTIFIKASI DOSEN. In SENSITIf: Seminar Nasional Sistem Informasi dan Teknologi Informasi (pp. 365-371) 